\title{
Influence of periodontal therapy on C-reactive protein level: a systematic review and meta- analysis
}

Camila Oliveira Teixeira de FREITAS ${ }^{1}$, Isaac Suzart GOMES-FILHO ${ }^{2}$, Roberta Catapano NAVES ${ }^{3}$, Getúlio da Rocha NOGUEIRA FILHO ${ }^{4}$, Simone Seixas da $\mathrm{CRUZ}^{5}$, Carlos Antonio de Souza Teles SANTOS ${ }^{6}$, Leonardo DUNNINGHAM Lituânia Fialho de MIRANDA ${ }^{8}$, Mônica Dourado da Silva BARBOSA ${ }^{9}$

\footnotetext{
1- MSc in Stomatology, Bahia School of Medicine and Public Health, Salvador, BA, Brazil. 2- PhD in Periodontics, Feira de Santana State University, Feira de Santana, BA, Brazil.

3- MSc in Stomatology, Bahia School of Medicine and Public Health, Salvador, BA, Brazil.

4- PhD in Periodontics, Bahia School of Medicine and Public Health, Salvador, BA, Brazil.

5- PhD in Epidemiology, Federal University of Bahia Recôncavo, Santo Antônio de Jesus, BA, Brazil.

6- PhD in Epidemiology, Feira de Santana State University, Feira de Santana, BA, Brazil.

7- Undergraduate student, Bahia School of Medicine and Public Health, Salvador, BA, Brazil.

8- Undergraduate student, Feira de Santana State University, Feira de Santana, BA, Brazil.

9- PhD in Periodontics, Bahia School of Medicine and Public Health, Salvador, BA, Brazil.
}

Corresponding address: Camila Oliveira Teixeira de Freitas - Av. Getúlio Vargas, 379, Centro - 44025-010 - Feira de Santana - BA - Brazil - e-mail: camila. otf@gmail.com

Received: October 07, 2009 - Modification: May 12, 2010 - Accepted: October 26, 2010

\section{ABSTRACT}

\begin{abstract}
The influence of oral infections, especially periodontal disease, on systemic diseases has been extensively discussed in the literature. Because periodontal disease is a persistent infection, it promotes an inflammatory response. C-reactive protein is a marker for inflammatory reactions that is frequently studied, since elevated levels of this protein are related to coronary events. Objective: The aim of this study was to investigate the effect of periodontal therapy on reducing the serum levels of C-reactive protein, by means of a systematic review of the literature and meta-analysis. Material and Methods: A systematic review of the English-language literature was conducted in the PUBMED-MEDLINE database, using the key words "periodontal disease", "C-reactive protein", "periodontal therapy" and "periodontal treatment", in accordance with the terms for Medical Subject Headings (MeSH), to evaluate the effect of periodontal therapy on $\mathrm{C}$-reactive protein levels. A qualitative analysis of studies of randomized clinical trial design was performed using CONSORT, with subsequent meta-analysis. Results: The literature search initially retrieved 46 potentially relevant studies available in the databases. From these, in accordance with the inclusion criteria, only 11 were selected, of which only 4 fulfilled the criteria of randomized clinical trial design. According to CONSORT, the studies evaluated generally presented good quality with regard to the criteria analyzed. Through meta-analysis, the reduction in mean levels of C-reactive protein $(-0.231 ; p=0.000)$ after introducing periodontal treatment was estimated. The result was statistically significant, without evidence of heterogeneity between the studies $(p=0.311)$. Conclusions: The findings indicated that non-surgical periodontal treatment had a positive effect with regard to reduction of the serum levels of C-reactive protein.
\end{abstract}

Key words: Meta-Analysis. Intervention studies. Periodontitis. Periodontal diseases.

\section{INTRODUCTION}

The association between oral diseases and systemic diseases has been extensively discussed in the scientific community. The main exposure measurement in most studies that have associated oral infections with systemic disease has been periodontal disease ${ }^{10,18}$.

Periodontal disease is an inflammatory process of multifactorial nature that takes place in the toothsupporting tissues in response to accumulation of bacteria, which are predominantly Gram-negative. 
Thus, a variety of risk factors such as the habit of smoking, presence of systemic diseases, use of medications and local biofilm retention, among others, may aggravate this clinical condition. Because of this multiplicity of factors, periodontal disease presents different degrees of progression, from the appearance of initial alterations to the periodontal tissues (such as gingivitis) to various severity levels of periodontitis.

Once the type of periodontal disease has been diagnosed, it can be successfully treated. Periodontal therapy aims to alter or eliminate the origin of the microorganisms and also to prevent progression of the disease, thereby preserving the state of health of such individuals and avoiding recurrence of periodontitis. Periodontal pathogens affect the immune system and promote local and systemic inflammatory responses ${ }^{14}$. Thus, periodontal therapy basically aims to control this inflammation.

Persistent localized infection may influence the systemic levels of inflammatory mediators. One of the markers for this inflammatory response is C-reactive protein, which is an acute-phase protein produced by various inflammatory stimuli such as trauma, infection and hypoxia. C-reactive protein levels guide decisions regarding diagnosis, monitoring and therapy for inflammatory processes and associated diseases ${ }^{6,15}$.

Recent studies have demonstrated a correlation between periodontitis and serum levels of C-reactive protein. It has been seen that its levels are generally higher in the presence of periodontal disease $\mathrm{e}^{5,16}$ and that, even if this inflammatory marker only presents a slight elevation, it may predispose individuals to coronary events. It has been shown that C-reactive protein plays a role in the pathogenesis of atherosclerosis, and recent evidence has associated periodontal disease with a high risk of formation of atherosclerotic plaque, which is the principal cause of all cardiovascular diseases. Chronic presence of periodontal disease may lead to changes in systemic conditions via two etiological pathways: (1) direct invasion of the periodontal pathogen into the arterial wall; and (2) release of inflammatory mediators in response to the inflammation, with atherogenic effect. C-reactive protein has a role in endothelial dysfunction. From this perspective, and with the recognition that more than $50 \%$ of the cases of cardiovascular diseases are not associated with classical risk factors, a chronic inflammatory process like periodontal disease may be considered to be an important complementary factor in this causal chain. The theory that sustains the hypothesis that periodontal infection may increase the serum levels of C-reactive protein is summarized in the chart below (Figure 1).

In this respect, and because of conflicting data regarding the topics of an association between periodontal disease and high levels of C-reactive protein and the use of periodontal therapy for reducing the levels of this protein, the aim of the present study was to conduct a systematic literature review and meta-analysis on the evidence that exists regarding the effect of periodontal treatment on the serum levels of C-reactive protein. A further aim was to evaluate the quality of the evidence encountered.

\section{MATERIAL AND METHODS}

\section{Literature search}

A systematic review of the literature was conducted on the effect of periodontal treatment on the serum levels of C-reactive protein, with a search for articles in the PUBMED/MEDLINE search site. In this, a single reviewer selected English-language articles published up to June 2007, using the key words "periodontal disease", "C-reactive protein", "periodontal therapy" and "periodontal treatment", in accordance with the terms for Medical Subject Headings $(\mathrm{MeSH})^{8}$.

\section{Inclusion criteria}

All English-language articles dealing with the effects of periodontal therapy on the serum levels of C-reactive protein among humans were selected, independent of the periodontal therapy applied. The selection was also made according to study design, searching for clinical trials. It is emphasized that, because of the small number of studies found to be available, no restrictions regarding sample size or type of therapy were imposed (Figure 2).

\section{Procedures for obtaining data}

A single reviewer screened the titles and abstracts from the electronic review to determine the inclusion criteria for the articles. Those that fitted the preestablished criteria were obtained in full. For studies that had been published more than once, having complementary results published in another article, the most complete article was selected, thus including the study only once. Subsequently, a chart compiling the following data of interest extracted from each investigation was created: author, year, study design, location where the research had been done, sample size, criteria used for determining the presence of periodontal disease, type of periodontal treatment used, C-reactive protein values before and after the therapy, method and time used for measuring C-reactive protein, and the result found, with its statistical significance value (Figure 4).

\section{Quality assessment}

The quality of the randomized clinical trials 


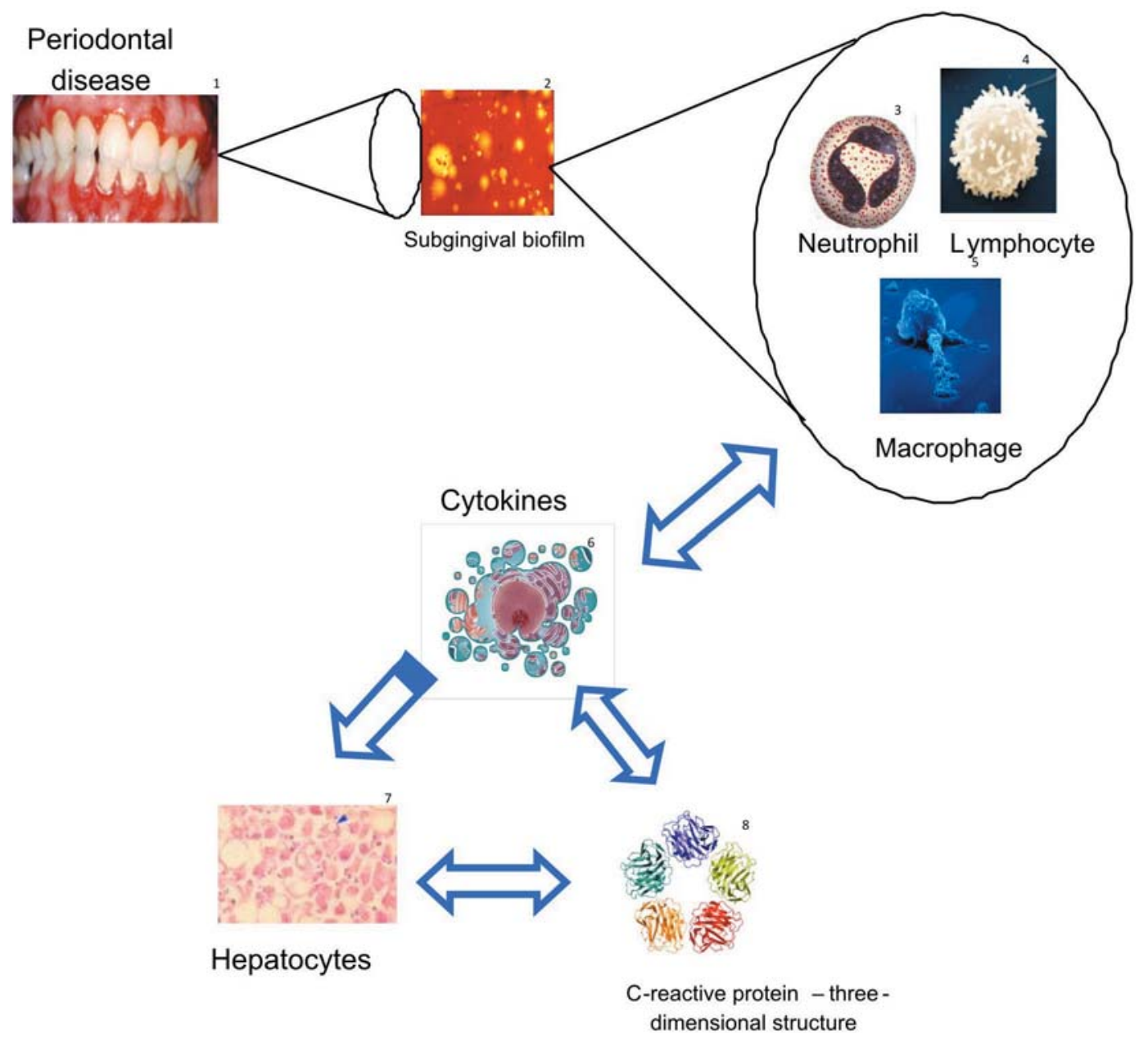

Figure 1- Biological plausibility diagram that periodontal infection may increase the serum levels of C-reactive protein

was assessed in accordance with CONSORT (Consolidated Standards of Reporting Trials) ${ }^{12}$. The criteria used for analyzing the quality were:

Allocation concealment: assessment of whether the allocation method used was random;

Masking technique: assessment of whether the study participants, the sample and/or the investigators were unaware of (blind to) the details of the study method and, if so, at what level (double blind or single blind);

Intervention procedures: precise data on the intervention, such as the specific technique applied;

Statistical analysis method: assessment of the statistical test used for analyzing the primary data, along with the additional methods for analyzing subgroups and making adjustments;

Losses: assessment of sample losses while carrying out the study.

\section{Statistical analysis}

Since the present study aimed to evaluate causal relationships between periodontal therapy and C-reactive protein levels, only studies with a randomized clinical trial design were chosen for analysis via meta-analysis. The objective was to summarize the mean effect of periodontal therapy in relation to C-reactive protein levels from a series of published studies.

To perform the meta-analysis, the mean difference and standard error estimated for each of the selected studies were used. The possibility of heterogeneity between the studies was checked by means of the heterogeneity test, through adjustment of a random-effects model (metacommand in STATA v.8). A forest plot graphical representation for a fixed-effects model was finally generated. For all procedures, a significance level of $5 \%(p \leq 0.05)$ was established. The statistical packed used was Stata version 8.0 (Stata, StataCorp, College Station, TX, USA).

\section{RESULTS}

\section{Literature search}

From the key words used, 46 potentially relevant articles were found, among which one was excluded because it was not in the English language and another was excluded because it used an animal model. Among the remaining 44, 33 were excluded because they did not use a study design of clinical trial type. Only 11 fulfilled the previously established inclusion criteria. Of these, 
only 4 presented the characteristic of randomization of the sample. Randomization was a fundamental criterion for investigating the causality between the effect of periodontal therapy and the level of C-reactive protein, i.e., the main objective of this systematic review ${ }^{2,4,7,17}$.

\section{Statistical analysis}

The four randomized clinical trials were combined into a single analysis using a fixed-effect model, since no heterogeneity was observed between the studies $(p=0.311)$ (Figure 3$)$. The general mean difference in C-reactive protein levels from before to after treatment was $-0.231 \mathrm{mg} / \mathrm{L}$, which was a statistically significant result $(p=0.000)$. Periodontal treatment was seen to be a statistically significant protective factor for the serum levels of C-reactive protein.
Figure 3 shows a forest plot graphical representation in which the mean differences in each study can be seen individually, along with the result from grouping them (shown by the diamond). On the left side of the figure, the studies used in the meta-analysis are listed. The horizontal lines represent $95 \%$ confidence intervals for mean differences (before and after) estimated for each study. It could be seen that the relatively small sample size led to lower precision and consequently confidence intervals of greater amplitude. The points above each horizontal line represent the mean difference in each study, such that the size of these points is directly proportional to the respective weight. If the horizontal line crosses the thick vertical line at the center of the graph, the $95 \%$ confidence interval then contains the value zero, which gives evidence that in the respective

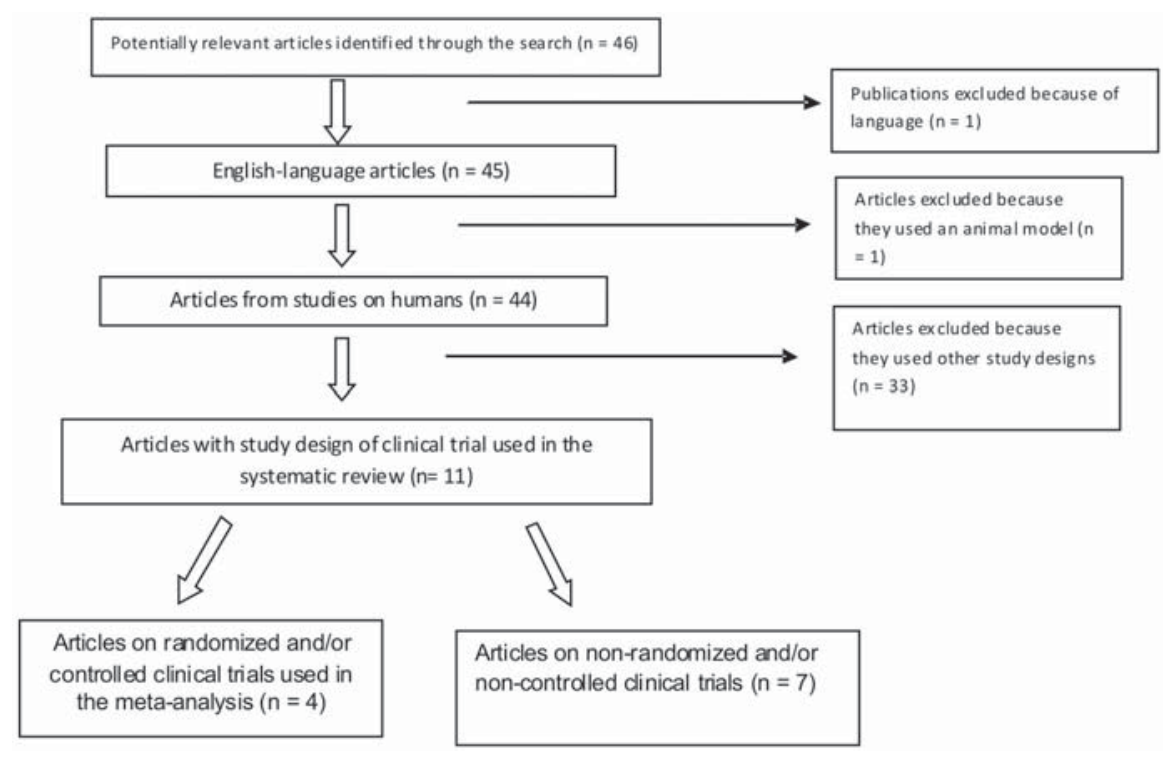

Figure 2- Article selection and inclusion process

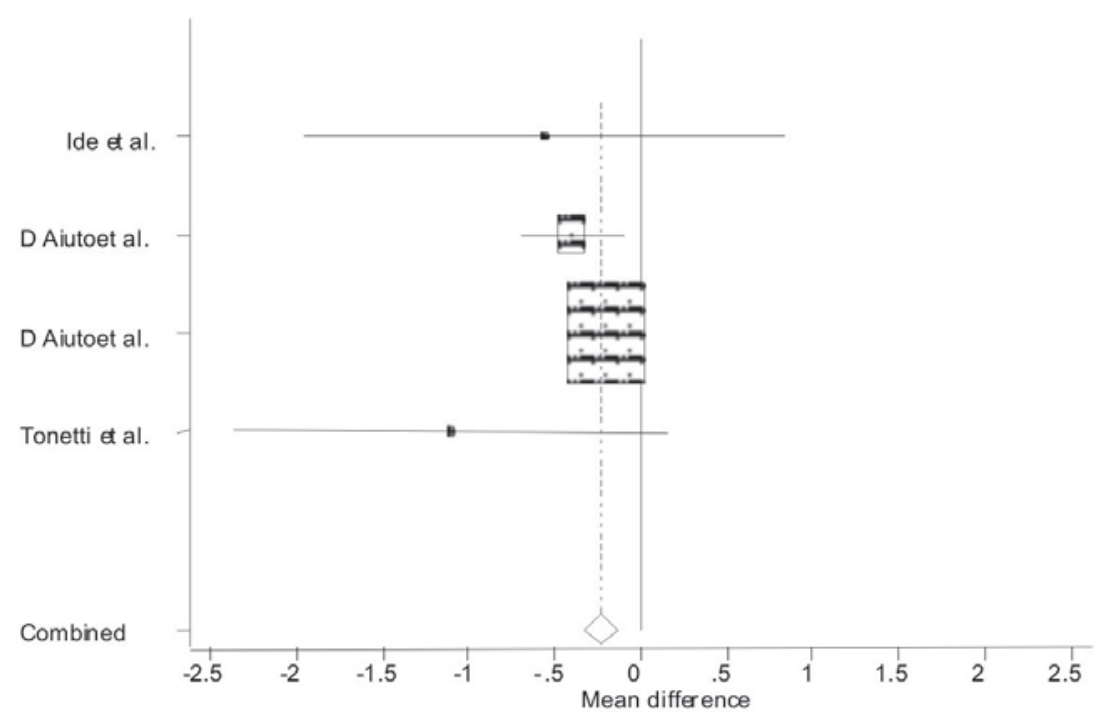

Figure 3- Changes in serum levels of C-reactive protein from before to after the periodontal treatment 


\begin{tabular}{|c|c|c|c|c|c|c|c|c|c|c|}
\hline Author & Year & $\begin{array}{l}\text { Type of } \\
\text { study }\end{array}$ & Location & Sample & $\begin{array}{l}\text { Criterion for } \\
\text { periodontal disease }\end{array}$ & $\begin{array}{c}\text { Type of } \\
\text { periodontal } \\
\text { therapy }\end{array}$ & $\begin{array}{l}\text { c-reactive } \\
\text { protein } \\
\text { values } \\
\text { (before) }\end{array}$ & $\begin{array}{l}\text { c-reactive } \\
\text { protein } \\
\text { values } \\
\text { (after) }\end{array}$ & $\begin{array}{l}\text { Result and } \\
\text { significance }\end{array}$ & $\begin{array}{c}\text { c-reactive protein } \\
\text { measurement }\end{array}$ \\
\hline Mattila, et al. ${ }^{11}$ & 2002 & Intervention & Finland & 35 & Bone loss $>25 \%$ teeth & $\begin{array}{c}\text { RSS+metronidazole } \\
500 \mathrm{mg}\end{array}$ & $1.05 \mathrm{mg} / \mathrm{L}$ & $0.7 \mathrm{mg} / \mathrm{L}$ & $\downarrow P=0.05$ & $\begin{array}{l}\text { Before and six } \\
\text { weeks after }\end{array}$ \\
\hline $\begin{array}{l}\text { Iwamoto, } \\
\text { et al. }{ }^{9}\end{array}$ & 2003 & Intervention & Japan & 15 & $\begin{array}{l}\text { Chronic severe } \\
\text { periodontitis }\end{array}$ & $\begin{array}{l}\text { Scaling with } \\
\text { ultrasound } \\
\text { device+topical } \\
\text { antibiotic }\end{array}$ & $1677 \mathrm{ng} / \mathrm{L}$ & $934.3 \mathrm{ng} / \mathrm{L}$ & $\downarrow(P<0.001)$ & $\begin{array}{c}\text { Before and after } \\
\text { therapy }\end{array}$ \\
\hline Ide, et al. ${ }^{7}$ & 2004 & $\begin{array}{l}\text { Randomized } \\
\text { intervention }\end{array}$ & England & 23 & $\begin{array}{c}\text { Minimum of five } \\
\text { teeth with a site with } \\
\text { attachment loss } \geq 5 \mathrm{~mm} \\
\text { and bone loss in at } \\
\text { least two quadrants }\end{array}$ & $\begin{array}{c}\text { OHG+conventional } \\
\text { SRP+SRP with } \\
\text { ultrasound }\end{array}$ & $4.02 \mathrm{mg} / \mathrm{L}$ & $3.46 \mathrm{mg} / \mathrm{L}$ & $\downarrow(P=0.44)$ & $\begin{array}{c}\text { Baseline and } 15,30, \\
60 \text { and } 120 \text { minutes } \\
\text { after therapy } 1\end{array}$ \\
\hline D'Aiuto, et al. ${ }^{3}$ & 2004 & Intervention & England & 94 & $\begin{array}{c}50 \% \text { of the teeth } \\
\text { presenting PD } \geq 6 \mathrm{~mm} \\
\text { and bone loss } \geq 30 \%\end{array}$ & $\mathrm{SRP}+\mathrm{OHG}$ & Not stated & Not stated & $\begin{array}{c}\downarrow 0.5 \mathrm{mg} / \mathrm{L} \text { on } \\
\text { average }\end{array}$ & $\begin{array}{c}\text { Baseline and two } \\
\text { and six months after } \\
\text { therapy }\end{array}$ \\
\hline D'Aiuto et al. ${ }^{1}$ & 2004 & Intervention & England & 14 & $\begin{array}{c}50 \% \text { of teeth } \\
\text { presenting PD } \geq 6 \mathrm{~mm} \\
\text { and bone loss } \geq 30 \%\end{array}$ & SRP in whole mouth & Not stated & Not stated & $\begin{array}{l}\text { †on first day } \\
\text { and } \downarrow \text { one } \\
\text { month after } \\
\text { baseline }\end{array}$ & $\begin{array}{c}\text { Baseline and } 1,3,5, \\
7 \text { and } 30 \text { days after } \\
\text { therapy }\end{array}$ \\
\hline D'Aiuto, et al. ${ }^{2}$ & 2005 & $\begin{array}{l}\text { Randomized } \\
\text { intervention }\end{array}$ & England & 65 & $\begin{array}{c}50 \% \text { of teeth } \\
\text { presenting PD } \geq 6 \mathrm{~mm} \\
\text { and bone loss } \geq 30 \%\end{array}$ & $\begin{array}{l}\text { Conventional } \\
\text { SRP+intensive } \\
\text { therapy }\end{array}$ & $\begin{array}{c}2.0+/-1.1 \\
\mathrm{mg} / \mathrm{L}^{*}\end{array}$ & $\begin{array}{c}1.6+/-0.9 \\
\mathrm{mg} / \mathrm{L}^{*}\end{array}$ & $\begin{array}{c}\downarrow 0.5 \mathrm{mg} / \mathrm{L} \\
\text { on average } \\
\mathrm{P}=0.011\end{array}$ & $\begin{array}{l}\text { Baseline and two } \\
\text { months after therapy }\end{array}$ \\
\hline $\begin{array}{c}\text { Yamazaki, et } \\
\text { al. }{ }^{19}\end{array}$ & 2005 & Intervention & Japan & 45 & $\begin{array}{c}\mathrm{PD}<4 \mathrm{~mm} ; 4-6 \mathrm{~mm} \text { or } \\
>6 \mathrm{~mm} .\end{array}$ & $\begin{array}{c}\mathrm{SRP}+\mathrm{OHG}+ \\
\text { surgery }\end{array}$ & $317 \mathrm{ng} / \mathrm{L}$ & $261.5 \mathrm{ng} / \mathrm{L}$ & $\downarrow \Delta$ & $\begin{array}{c}\text { Baseline and } \\
\text { three months after } \\
\text { treatment }\end{array}$ \\
\hline $\begin{array}{l}\text { Montebugnoli, } \\
\text { et al. }{ }^{13}\end{array}$ & 2005 & Intervention & Italy & 20 & CPSS and CRSS & $\begin{array}{l}\text { OHG in two } \\
\text { visits+manual } \\
\text { SRP+SRP with } \\
\text { ultrasound in four } \\
\text { visits }\end{array}$ & $4.33 \mathrm{mg} / \mathrm{L}$ & $3.42 \mathrm{mg} / \mathrm{L}$ & $\begin{array}{l}\text { CPSS: } \downarrow \\
(P<0.05)\end{array}$ & $\begin{array}{l}\text { Baseline and three } \\
\text { months after therapy }\end{array}$ \\
\hline D'Aiuto et al. ${ }^{4}$ & 2006 & $\begin{array}{l}\text { Randomized } \\
\text { controlled } \\
\text { intervention }\end{array}$ & England & 40 & $\begin{array}{c}50 \% \text { of teeth } \\
\text { presenting bone loss } \\
>4 \mathrm{~mm}\end{array}$ & $\begin{array}{l}\text { SRP in a single } \\
\text { session+local } \\
\text { antibiotic, or only } \\
\text { SRP in a single } \\
\text { session }\end{array}$ & $\begin{array}{c}1.8+/-1.1 \\
\mathrm{mg} / \mathrm{L}^{*}\end{array}$ & $\begin{array}{c}1.6+/-2.0 \\
\mathrm{mg} / \mathrm{L}^{*}\end{array}$ & $\downarrow P<0.05$ & $\begin{array}{c}\text { Baseline and 1, } 2 \\
\text { and } 6 \text { months after } \\
\text { therapy }\end{array}$ \\
\hline $\begin{array}{l}\text { loannidou, } \\
\text { et al. }{ }^{8}\end{array}$ & 2006 & Meta-analysis & USA & --- & ---- & ------ & ----- & ------ & $\begin{array}{c}\text { No } \\
\text { difference }\end{array}$ & -- \\
\hline Tonetti ,et al. ${ }^{17}$ & 2007 & $\begin{array}{l}\text { Randomized } \\
\text { controlled } \\
\text { intervention }\end{array}$ & USA & 120 & $\begin{array}{l}\text { More than } 50 \% \text { of } \\
\text { teeth presenting } \\
\text { probing depth }>6 \mathrm{~mm} \\
\text { and attachment loss } \\
\quad>30 \%\end{array}$ & $\begin{array}{l}\text { Intensive therapy } \\
\text { in a single } \\
\text { session+local } \\
\text { antibiotic }\end{array}$ & $\begin{array}{c}2.5+/-2.7 \\
\mathrm{mg} / \mathrm{L}^{*}\end{array}$ & $1.4 \mathrm{mg} / \mathrm{L}^{*}$ & $\downarrow p=0.09$ & $\begin{array}{c}\text { Baseline and } 1,7, \\
30,60 \text { and } 180 \text { days } \\
\text { after therapy } 2\end{array}$ \\
\hline
\end{tabular}

$\mathrm{CVD}=$ cardiovascular disease, $\mathrm{SRP}=$ scaling and root planning, $\downarrow=$ diminished, OHG=oral hygiene guidance, $\mathrm{BMI}=$ body mass index, CPSS=clinical periodontal sum score, CRSS=clinical and radiographic sum score, PD=probing depth, $\Delta=$ no statistical significance

* Only the results from intensive therapy were presented

1 The data collected represent the baseline time and 120 minutes later

2 The data collected represent the baseline time and two months later

Figure 4- Schematic summary of published studies that evaluated the effect of periodontal therapy on the serum levels of C-reactive protein 


\begin{tabular}{|c|c|c|c|c|c|}
\hline & $\begin{array}{l}\text { Allocation } \\
\text { concealment }\end{array}$ & $\begin{array}{l}\text { Masking } \\
\text { technique }\end{array}$ & $\begin{array}{l}\text { Intervention } \\
\text { procedure }\end{array}$ & $\begin{array}{l}\text { Statistical } \\
\text { analysis method }\end{array}$ & Attrition \\
\hline $\begin{array}{l}\text { Ide, et al. }{ }^{7} \\
(2004)\end{array}$ & $\begin{array}{l}\text { Positive (no method } \\
\text { cited) }\end{array}$ & Not cited & $\begin{array}{l}\text { Positive (full-mouth } \\
\text { instrumentation with } \\
\text { manual technique } \\
\text { and with ultrasound) }\end{array}$ & $\begin{array}{c}\text { Positive ( } T \text { test or } \\
\text { Wilcoxon; ANOVA and } \\
\text { Spearman) }\end{array}$ & $2.5 \%$ \\
\hline $\begin{array}{l}\text { D'Aiuto, et al. }{ }^{2} \\
\qquad(2005)\end{array}$ & $\begin{array}{c}\text { Positive (random } \\
\text { permuted block } \\
\text { approach; allocation was } \\
\text { concealed by the use of } \\
\text { opaque envelopes) }\end{array}$ & $\begin{array}{l}\text { Positive } \\
\text { (single) }\end{array}$ & $\begin{array}{l}\text { Positive (intensive } \\
\text { periodontal } \\
\text { treatment in a single } \\
\text { session*) }\end{array}$ & $\begin{array}{c}\text { Positive(chi-squared, } \\
\text { ANOVA, Bonferroni, and } \\
\text { adjustment for covariables) }\end{array}$ & Unreported \\
\hline $\begin{array}{l}\text { D'Aiuto, et al. }{ }^{4} \\
\qquad(2006)\end{array}$ & $\begin{array}{c}\text { Positive (random } \\
\text { permuted block } \\
\text { approach; allocation was } \\
\text { concealed by the use of } \\
\text { opaque envelopes) }\end{array}$ & Not cited & $\begin{array}{l}\text { Positive (intensive } \\
\text { periodontal } \\
\text { treatment in a single } \\
\text { session) }\end{array}$ & $\begin{array}{c}\text { Positive ( } T \text { test, chi- } \\
\text { squared, ANOVA, } \\
\text { Bonferroni, Spearman) }\end{array}$ & Unreported \\
\hline $\begin{array}{l}\text { Tonetti, et al. }{ }^{17} \\
\qquad(2007)\end{array}$ & $\begin{array}{l}\text { Positive (patients were } \\
\text { randomly assigned with } \\
\text { the use of a computer- } \\
\text { generated table) }\end{array}$ & $\begin{array}{l}\text { Positive } \\
\text { (single) }\end{array}$ & $\begin{array}{l}\text { Positive (intensive } \\
\text { periodontal } \\
\text { treatment in a single } \\
\text { session*) }\end{array}$ & $\begin{array}{c}\text { Positive (ANOVA, Fischer, } \\
\text { Bonferroni, ...) }\end{array}$ & $5 \%$ \\
\hline
\end{tabular}

Figure 5- Qualitative evaluation of the randomized clinical trials included in the meta-analysis

study, the effect of the treatment on the occurrence of the event is non-significant (the interpretation is analog and usually done when the $p$ value is greater than $5 \%$ ). For example, in Figure 3, it can be seen that the confidence interval associated with the study by Ide, et al. ${ }^{7}$ (2004) contains the value zero, thus indicating that its respective mean difference is non-significant. On the other hand, it can be seen that that study has a smaller sample size than the others do, which suggests the possibility that the reason why significance was not reached was the small number of participants in the study.

When the confidence intervals touch or cross the line representing the value zero, it needs to be considered that the results from the study did not, in themselves, reach statistical significance, i.e. there was no difference between before and after the experimental treatment.

\section{Analysis of study methods}

Most of the 11 studies used in the review chose non-surgical treatment consisting of scaling and root planning in a single session. Different techniques were used for evaluating the C-reactive protein levels, namely: nephelometry ${ }^{7,19}$, ELISA test ${ }^{11,17}$, immunoturbidimetry test $\mathrm{t}^{1,2,3,4}$, unspecified high-sensitivity test from commercial laboratory ${ }^{9}$ and high-sensitivity commercial kit for measuring C-reactive protein in humans ${ }^{13}$ (Figure 4).

It is also emphasized that, among the 11 articles that fully fitted within the inclusion criteria, 10 presented reduced C-reactive protein levels after the periodontal therapy.

\section{Analysis of clinical trial quality}

The quality of the studies of randomized clinical trial type was also observed (Figure 5). Although there were only a small number of such studies, they presented the method used in detail, thus fulfilling the CONSORT assessment criteria ${ }^{12}$. Except for the study by Ide, et al. ${ }^{7}$ (2004), the way the individuals were allocated for periodontal treatment was not observed, other than the type of masking technique used. In the study by D'Aiuto, et al. ${ }^{2}$ (2005), the masking method used was single blinding, in which the effect of the periodontal treatment at the baseline and two months after the periodontal treatment was evaluated. Two treatment methods were used in that study, and significant reductions in C-reactive protein values were observed using both therapies. In the third randomized trial by D'Aiuto, et al. ${ }^{4}$ (2006), a similar methodology was adopted, but the evaluation period was extended and included $\mathrm{C}$-reactive protein analysis at the baseline and one, two and six months after the therapy. Their results suggested that intensive periodontal treatment reduced this and other inflammatory markers. Finally, in the most recent randomized clinical trial on this topic, Tonetti, et al. ${ }^{17}$ (2007) conducted a double-blind study on two groups of individuals, using two types of periodontal treatment to evaluate endothelial function. In addition, they analyzed inflammatory markers at the times of $1,7,30,60$ and 180 days after the treatment, and concluded that intensive periodontal treatment resulted in an immediate acute systemic inflammatory response of short-term nature, with 
alteration of endothelial function. After 7 days, the results showed that there had been a reduction in the inflammatory marker values (for example, C-reactive protein), and a large improvement in endothelial function.

\section{DISCUSSION}

The findings from the present meta-analysis study among randomized clinical trials indicate that non-surgical periodontal treatment has a positive effect in reducing the serum levels of C-reactive protein, with statistically significant results. The importance of these findings lies in its incipient reflection of the evidence accumulated over the last decade associating severe periodontitis with a high propensity to atherosclerosis, which is the main cause of cardiovascular diseases. On the other hand, these findings go against those of Ioanidou, et al. ${ }^{8}$ (2006), who conducted a systematic review and meta-analysis with the same objective and did not find statistical significance between periodontal treatment and serum levels of C-reactive protein, even though these authors had said that there were general indications that periodontal therapy did have an effect on the levels of this acute-phase protein.

The positive result from the present study regarding the effect of periodontal treatment on the serum levels of C-reactive protein, through using meta-analysis, is probably due to the greater number of studies that now exist in the literature on this topic: twice as many as were evaluated by Ioanidou, et al. ${ }^{8}$ (2006). This increase represents greater power in the analysis and is reflected in the empirical results attained. Although the number of studies analyzed was still small, this did not seem to interfere with the statistical significance. Hence, our confidence in our findings regarding the hypothesis that periodontal therapy has a reductive effect on C-reactive protein levels is increased.

Added to this is the fact that the present investigation to evaluate C-reactive protein levels before and after periodontal therapy only included studies with a randomized clinical trial design. In the epidemiological literature, the fundamental role of this study design for evaluating the cause-effect process is well recognized and is the gold standard for causality analyses. Although there are studies (generally cross-sectional studies) presenting increased C-reactive protein levels in individuals with periodontitis, in comparison with healthy individuals $\mathrm{s}^{5,10,14}$, they do not represent a causal relationship and may merely reflect confounding with other common risk factors for both periodontal disease and atherosclerosis, like smoking, obesity and diabetes. In the present systematic review, only 4 studies fulfilled the inclusion criteria and they all presented reduced serum levels of C-reactive protein after the periodontal treatment. Moreover, after statistical analysis of the C-reactive protein values before and after the periodontal treatment, two of these studies presented statistically significant results ${ }^{2,4}$, as shown in Figure 3.

It should also be highlighted that the heterogeneity analysis between the studies showed that there was no difference between them, possibly because the designs of the studies selected were similar as a result of the preestablished criteria. It should also be emphasized that, of the 4 studies that fulfilled all criteria for selection, 3 were produced by the same research group, thus conferring greater homogeneity to the comparison between the studies.

Other two important characteristics selected for analysis in the present study were the times when the serum level of C-reactive protein was measured and the type of periodontal therapy used. Among the studies evaluated, a variety of times was used for measuring the serum level of C-reactive protein (ranging from 15 min to 6 months), as well as different lengths of periodontal treatment. For analysis purposes, care was taken to always include the serum C-reactive protein values for the same point in time, at around two months, except in the study by Ide, et al. ${ }^{7}$ (2004), for which the last evaluation time of 120 min was used. With regard to the periodontal therapy, it was also decided to include the C-reactive protein values from groups that had similar treatments.

The periodontal therapy used in these studies was shown to significantly reduce the serum levels of C-reactive protein. It can also be highlighted that the results achieved could have been better, given that the type of periodontal treatment used was non-surgical and was often administered in a single session. It is also known that severe periodontitis may require complementary surgical treatment at sites in which there has been more severe progression of the periodontal disease and the conservative treatment used has been insufficient to restore the periodontal tissues to normality ${ }^{17}$. In the studies investigated, no surgical procedures were used among the samples.

It should also be noted that before the small number of studies evaluated in this meta-analysis, two important diagnostic tests for publication bias and time trend were not performed. Publication bias is a well known phenomenon in clinical literature, in which positive results have a better chance of being published, are published earlier, and are published in journal with higher impact factors. On the other hand, time trend is a technique to aid interpretation of data, determining if measurements exhibit an increasing or decreasing trend.

In the light of the perspectives presented and 
the evidence in the literature, the present study has demonstrated that non-surgical periodontal therapy has a reductive effect on the serum levels of C-reactive protein, noting that genetic variability may be influenced the findings of the present study and others factors that could not be measured. However, in view of the importance of this topic for public health, given that high levels of this acute-phase protein have been associated with cardiovascular diseases, which are responsible for human mortality rates of around $40 \%$ worldwide, further studies with better delineation need to be conducted to confirm these results and improve their external validity.

\section{CONCLUSION}

Although the findings from this systematic review and meta-analysis have been favorable towards periodontal treatment for reducing the serum levels of C-reactive protein, and there is wide evidence indicating that the serum levels of C-reactive protein are high in individuals with chronic severe periodontal disease, the discussion on this hypothesis has not been exhausted. The importance of this topic demands that many other randomized clinical trials should be carried out to broaden the body of evidence regarding reductions in serum levels of C-reactive protein among individuals whose periodontitis has been treated, so that it can be categorically stated that there are no areas with localized inflammation, since only non-surgical treatment has been carried out in the studies examined in this systematic review. In addition, sample size calculations, repeated scaling and root planning sessions and support therapy for the periodontal treatment are conditions that may bring more robust results in the future that favor this therapy.

\section{REFERENCES}

1- D'Aiuto F, Nibali L, Mohamd-Ali V, Vallance P, Tonetti MS. Periodontal therapy: a novel non-drug-induced experimental model to study human inflammation. J Periodontal Res. 2004;39:294-9. 2- D'Aiuto F, Nibali L, Parkar M, Suvan J, Tonetti MS. Short-term effects of intensive periodontal therapy on serum inflammatory markers and cholesterol. J Dent Res. 2005;84:269-73.

3- D'Aiuto F, Parkar M, Andreou G, Brett PM, Ready D, Tonetti MS. Periodontitis and atherogenesis: causal association or simple coincidence? J Clin Periodontol. 2004;31:402-11.
4- D'Aiuto F, Parkar M, Nibali L, Suvan J, Lessem J, Tonetti MS. Periodontal infections cause changes in traditional and novel cardiovascular risk factors: results from a randomized controlled clinical trial. Am Heart J. 2006;151:977-84.

5- Ebersole JL, Machen RL, Steffen MJ, Willmann DE. Systemic acute-phase reactants, C-reactive protein and haptoglobin, in adult periodontitis. Clin Exp Immunol. 1997;107:347-52.

6- Glurich I, Grossi S, Albini B, Ho A, Shah R, Zeid M, et al. Systemic inflammation in cardiovascular and periodontal disease: comparative study. Clin Diagn Lab Immunol. 2002;9:425-32.

7- Ide M, Jagdev D, Coward PY, Crook M, Barclay GR, Wilson RF. The short-term effects of treatment of chronic periodontitis on circulating levels of endotoxin, C-reactive protein, tumor necrosis factor-alpha, and interleukin-6. J Periodontol. 2004;75:420-8.

8- Ioannidou E, Malekzadeh T, Dongari-Bagtzoglou A. Effect of periodontal treatment on serum C-reactive protein levels: a systematic review and meta-analysis. J Periodontol. 2006;77:163542.

9- Iwamoto Y, Nishimura F, Soga Y, Takeuchi K, Kurihara M, Takashiba $S$, et al. Antimicrobial periodontal treatment decreases serum C-reactive protein, tumor necrosis factor-alpha, but not adiponectin levels in patients with chronic periodontitis. J Periodontol. 2003; 74:1231-6.

10- Loss BG, Craandijk J, Hoeck FJ, Wertheim-van Dillem PME, Van Der Velden U. Elevation of systemic markers related to cardiovascular diseases in the peripheral blood of periodontitis patients. J Periodontol. 2000;74:1528-34.

11- Mattila K, Vesanen M, Valtonen V, Nieminem M, Palosuo T, Rasi $V$, et al. Effect of treating periodontitis on $C$-reactive protein levels: a pilot study. BMC Infect Dis. 2002;2:30.

12- Moher D, Schulz KF, Altman DG. The CONSORT statement: revised recommendations for improving the quality of reports of parallel-group randomized trials. Lancet. 2001;357:1191-4.

13- Montebugnoli L, Servidio D, Miaton RA, Prati C, Tricoci P, Melloni $C$, et al. Periodontal health improves systemic inflammatory and haemostatic status in subjects with coronary heart disease. J Clin Periodontol. 2005;32:188-92.

14- Noack B, Genco RJ, Trevisan M, Grossi S, Zambon JJ, Nardin ED. Periodontal infections contribute to elevated systemic C-reactive protein level. J Periodontol. 2001;72:1221-7.

15- Pepys MB, Hirschfield GM. C-reactive protein: a critical update. J Clin Invest. 2003;111:1805-12.

16- Slade GD, Offenbacher S, Beck JD, Heiss G, Pankow JS. Acutephase inflammatory response to periodontal disease in the US population. J Dent Res. 2000;79:49-57.

17- Tonetti MS, D'Aiuto F, Nibali L, Donald A, Storry C, Parkar, M, et al. Treatment of periodontitis and endothelial function. $\mathrm{N}$ Engl J Med. 2007;356:911-20.

18- Wakai K, Kawamura T, Umemura O, Hara Y, Machida J, Anno $\mathrm{T}$, et al. Associations of medical status and physical fitness with periodontal disease. J Clin Periodontol. 1999;26:664-72.

19- Yamazaki K, Honda T, Oda T, Ueki-Maruyama K, Nakajima T, Yoshie $\mathrm{H}$, et al. Effect of periodontal treatment on the $\mathrm{C}$-reactive protein and proinflammatory cytokine levels in Japanese periodontitis patients. J Periodontal Res. 2005;40:53-8. 